\title{
PENGARUH STRES KERJA DAN KEPUASAN KERJA TERHADAP KINERJA KARYAWAN PT. BPR SEDANA MURNI
}

\author{
K.S. Wirya ${ }^{1}$, N.D. Andiani ${ }^{2}$, N.L.W.S. Telagawathi ${ }^{3}$ \\ 1,2,3 Jurusan Manajemen, Universitas Pendidikan Ganesha, Singaraja \\ e-mail: sadawirya00@gmail.com, demeilovedini@gmail.com, gemilangsuryawan@gmail.com
}

\begin{abstract}
Abstrak
Penelitian ini bertujuan untuk memperoleh temuan eksplanatif yang teruji tentang pengaruh (1) stres kerja dan kepuasan kerja terhadap kinerja karyawan, (2) stres kerja terhadap kepuasan kerja, (3) stres kerja terhadap kinerja karyawan, dan (4) kepuasan kerja terhadap kinerja karyawan pada PT. BPR Sedana Murni. Penelitian ini menggunakan desain penelitian kuantitatif kausal. Subjek penelitian adalah seluruh karyawan PT. BPR Sedana Murni, dan objek penelitian adalah stres kerja, kepuasan kerja, dan kinerja karyawan. Populasi dalam penelitian ini berjumlah 32 karyawan. Semua populasi ini dijadikan unit pengamatan, sehingga penelitian ini termasuk penelitian populasi. Teknik pengumpulan data dalam penelitian adalah (1) pencatatan dokumen, dan (2) kuesioner, kemudian dianalisis menggunakan analisis jalur. Hasil penelitian menunjukan ada pengaruh dari (1) stres kerja dan kepuasan kerja terhadap kinerjakaryawan, (2) stres kerja berpengaruh negatif terhadap kepuasan kerja, (3) stres kerja berpengaruh negatif terhadap kinerja karyawan, dan (4) kepuasan kerja berpengaruh positif terhadap kinerja karyawan pada PT. BPR Sedana Murni.
\end{abstract}

Kata-kata kunci: stres kerja, kepuasan kerja, kinerja karyawan

\begin{abstract}
This present study was intended to find the teasted explanative finding of the impact of (1) work stress and job satisfaction on employee performance, (2) work stress on the job satisfaction, (3) work stress on employee performance, and (4) job satisfaction with employee performance at PT. BPR Sedana Murni. This study uses a causal quantitative research design. Research subjects were all employees of PT. BPR Sedana Murni, and the object of research is job stress, job satisfaction, and employee performance. The population in this study amounted to 32 employees. All of these populations were made into observation units, so this study was included as population research. Data collection techniques in research are (1) document recording, and (2) questionnaire, then analyzed using path analysis. The results showed there was an influence of (1) work stress and job satisfaction on employee performance,(2) work stress has a negative effect on job satisfaction, (3) work stress has a negative effect on employee performance, and (4) job satisfaction has a positive effect on employee performance at PT. BPR Sedana Murni.
\end{abstract}

Keywords: work stress, job satisfaction and work stress

\section{PENDAHULUAN}

Perkembangan perusahaan yang bergerak dibidang lembaga keuangan saat ini semakin berkembang dan bertumbuh. Pertumbuhan lembaga keuangan khususnya perbankan sangat dibutuhkan oleh masyarakat dalam bentuk kredit, tabungan dan deposito ini bertujuan untuk meningkatkan kesejahtraan hidup. Perbankan dibagi menjadi dua yaitu Bank Umum dan Bank Perkreditan Rakyat (BPR), Bank Umum adalah organisasi yang memberikan jasa yang sifatnya umum yang mempunyai arti memberikan semua jasa perbankan miliki, sedangkan Bank Perkreditan rakyat adalah organisasi yang kegiatanya lebih sempit dimana BPR menerima dana dari masyarakat dan menyalurkannya ke masyarakat.

Sumber daya manusia merupakan unsur penting dalam memajukan suatu perusahaan. Menurut Ndraha (dalam Sutrisno 2009: 4) sumber daya manusia berkualitas tinggi adalah sumber daya manusia yang mampu menciptakan keunggulan bukan hanya dengan kemampuan fisik, tapi juga harus diimbangi dengan kreatifitas dan inovasi. Sumber daya manusia yang berkualitas sangat dibutuhkan terutama pada bagian pemasaran, 
karena bagian terpenting dalam suatu bisnis penjualan tekstil ini terletak di bagian pemasaran.

Di Bali, khususnya di daerah Tabanan kebutuhan akan lembaga keuangan semakin meningkat, salah satunya adalah peran Bank Perkreditan Rakyat (BPR) yang keberadaanya dapat membantu meningkatkan perekonomi masyarakat sekitar khususnya masyarakat yang memiliki usaha atau industri rumahan. Keberadaan BPR dalam lingkungan masyarakat tidak akan berjalan maksimal tanpa adanya dukungan dari sumber daya manusia (SDM) khususnya karyawan perusahaan. Menurut Sutrisno (2009: 4) sumber daya manusia yang berkualitas tinggi adalah sumber daya manusia yang mampu menciptakan keunggulan bukan hanya dengan kemampuan fisik, tapi juga harus diimbangi dengan kreatifitas dan inovasi, dengan memiliki sumber daya manusia yang berkualitas perusahaan mampu terus bersaing.

Meningkatnya kebutuhan akan perbankan khususnya daerah Tabanan, salah satu perusahaan perbankan yang ikut bersaing ialah PT. BPR Sedana Murni yang beralamat di jalan Melati No. 26 Bajera kec. Selemadeg - Tabanan dan memiliki 32 orang karyawan. Perusahaan PT. BPR Sedana Murni yang bergerak di bidang lembaga keuangan berperan penting dalam membantu usaha kecil dan menengah untuk berkembang kususnya dalam bentuk modal usaha, PT. BPR Sedana Murni memiliki 3 produk yaitu tabungan, deposito dan kredit. Dari observasi awal yang dilakukan di PT. BPR Sedana Murni didapat data target dan realisasi pendapatan operasional yang menunjukan penurunan kinerja dari bulan Januari sampai Desember tahun 2019, Hal ini dapat dilihat pada Gambar Grafik 2.1.

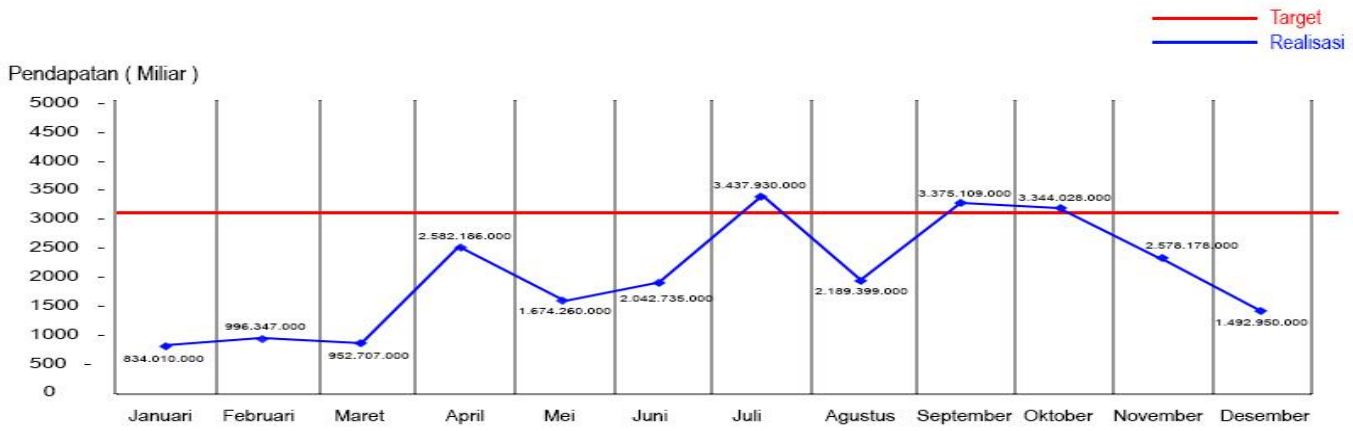

Sumber : PT. BPR Sedana Murni (2019)

Gambar 1 Data Target dan Realisasi Pendapatan Operasional

PT. BPR Sedana Murni Bulan Januari sampai Desember 2019

Berdasarkn Gambar 1 menunjukan target dan realisasi pendapatan operasional pada PT. Sedana Murni mengalami penurunan pada Bulan September sampai Desember, penurunan Bulan September sampai Oktober sebesar 0,1\%, di Bulan Oktober sampai November sebesar $29 \%$ dan pada bulan November sampai Desember sebesar $70 \%$. Penurunan realisasi pendapatan oprasional menunjukan adanya penurunan kinerja karyawan pada perusahaan PT. BPR Sedana Murni, selain itu kemampuan karyawan dalam menjelaskan produk atau jasa yang dimiliki PT. BPR Sedana Murni masih kurang dikuasai, ini menyebabkan konsumen kurang tertarik mendengarkan penyampaian mengenai produk atau jasa yang ditawarkan dan beranggapan hanya membuang-buang waktu saja.

Kinerja karyawan merupakan hasil kerja yang dicapai seseorang atau sekelompok orang dalam mencapai tujuan perusahaan diukur selama periode waktu tertentu berdasarkan ketentuan atau kesepakatan yang telah ditetapkan sebelumnya. Menurut Handoko (2008) menyatakan bahwa stres kerja dan kepuasan kerja dapat memengaruhi kinerja karyawan itu sendiri, jadi dapat disimpulkan jika stres kerja dapat dikelola dengan baik akan membuat karyawan merasa puas dalam bekerja yang berdampak pada 
pencapaian kinerja karyawan mencapai maksimal. Teori tersebut sejalan dengan hasil penelitian oleh Wala (2017) bahwa stres kerja dan kepuasan kerja secara simultan berpengaruh signifikan terhadap kinerja karyawan.

Stres kerja merupakan kodisi seseorang yang tertekan karena ketidakmampuan dalam menyelesaikan tugas yang diberikan oleh perusahaan. Menurut Sasono (2004: 5) menyebutkan bahwa dampak negatif stres kerja dengan tingkat yang tinggi akan berdampak pada penurunan kinerja karyawan yang drastis. Hal ini sejalan dengan hasil penelitian yang dilakukakan Amalia (2017) stres kerja berpengaruh negatif terhadap kinerja karyawan, research gap dimana stres kerja terjadi karena konflik antara karyawan. Berbeda dengan hasil penelitian Annisa (2017) stres kerja berpengaruh positif terhadap kinerja karyawan penelitian ini lebih mengarah kepada permasalahan piskologi dari subjek yang diteliti.

Berdasarkan observasi awal yang dilakukan terhadap karyawan PT. BPR Sedana Murni memperoleh hasil bahwa stres kerja yang dialami karyawan cukup tinggi. Karyawan merasa tertekan karena target yang ditetapkan perusahaan cukup tinggi dan belum dapat dicapai secara optimal oleh karyawanya, target dan realisasinya dapat dilihat pada Gambar 1 Permasalahan lain yaitu salah satunya pada bagian kredit karyawan merasa berat karena penempatan tugas tidak sesuai dengan asalnya, ada karyawan yang mendapat tugas jauh dari rumah asalnya. Karyawan juga kadang-kadang harus menggunakan uang sendiri supaya tidak kena penalti dari perusahaan karena tidak mencapai target yang ditentukan.

Kepuasan kerja perlu diperhatikan oleh manajer perusahaan, jika karyawan merasa puas dalam menjalankan pekerjaannya maka dapat mendorong kinerja karyawan tersebut menjadi maksimal. Robbins (2006) menyatakan Karyawan yang merasa puas akan pekerjaan yang mereka kerjakan memiliki kemungkinan yang lebih besar membicarakan hal yang positif tentang perusahaan, membantu yang lain dan membuat kinerja pekerjaan mereka mencapai maksimal. Hal ini sejalan dengan hasil penelitian Sari (2018) kepuasan kerja mempunyai hasil positif dan signifikan terhadap kinerja karyawan, penelitian ini menemukan fenomena mengenai kurang adilnya atasan sebab apa yang diungkapkan karyawan berbeda dengan tim perusahaan. Berbeda dengan hasil penelitian Kristine (2017) kepuasan kerja memiliki pengaruh negatif dan signifikan terhadap kinerja karyawan, karyawan kurang puas dengan pengambilan keputusan yang diabil perusahaan yang meningkatkan beban kerja untuk mendapatkan kinerja karyawan yang maksimal.

Fenomena yang terjadi pada perusahaan PT. BPR Sedana Murni dilihat dari indikator promosi, karyawan merasa kurang puas dikarenakan tidak adanya persyaratan yang pasti mengenai promosi jabatan dan penilaian yang dilakukan oleh atasan dinilai secara subjektif, tidak menggunakan aturan yang jelas dalam penilaian kinerja karyawannya. Selain itu uang lembur karyawan sering terpending sampai tiga bulan lebih karena keterlambatan perekapan data lembur karyawan.

Berdasarkan pada latar belakang masalah diatas, bahwa PT. BPR Sedana Murni memiliki peran penting dalam pengembangan perekonomian kususnya daerah Tabanan Kec. Selemadeg. Akan tetapi PT. BPR Sedana Murni masih kurang optimal dilihat dari data pencapaian bagian kredit yang menurun dari Bulan Januari sampai Desember 2019, peneliti tertarik melakukan penelitian dengan judul "Pengaruh Stres Kerja dan Kepuasan Kerja Terhadap Kinerja Karyawan PT. BPR Sedana Murni".

\section{KAJIAN PUSTAKA DAN PERUMUSAN HIPOTESIS \\ Kinerja Karyawan}

Menurut Hamzah dan Lamatenggo (2012) kinerja karayawan adalah perilaku seseorang yang membuahkan hasil kerja tertentu setelah memenuhi sejumlah persyaratan. Menurut Edison dkk (2017: 188) "kinerja adalah hasil dari suatu proses yang mengacu dan diukur selama periode waktu tertentu berdasarkan ketentuan atau kesepakatan yang telah ditetapkan sebelumnya". Menurut Mangkunegara (2013) kinerja karyawan merupakan hasil kerja secara kualitas dan kuantitas yang dicapai karyawan dalam menyelesaikan pekerjaanya. Kinerja merupakan kesuksesan karyawan dalam melaksanakan suatu 
pekerjaan, jadi dari teori para ahli diatas dapat disimpulkam bahwa kinerja adalah pencapaian yang seseorang atau sekelompok orang lakukan dalam suatu organisasi yang bertujuan untuk mencapai tujuan dari organisasi.

Menurut Edison dkk (2017: 193) dimensi kinerja ada empat adalah sebagai berikut. (1) Target, merupakan indikator terhadap pemenuhan jumlah barang, pekerjaan, atau jumlah uang yang dihasilkan. (2) Kualitas terhadap hasil kerja yang dicapai, dan ini adalah elemen penting, karena kualitas merupakan kekuatan dalam mempertahankan kepuasan kerja. (3) waktu penyelesaian, Penyelesaian yang tepat waktu dan penyerahan pekerjaan menjadi pasti. Ini adalah modal untuk membuat kepercayaan konsumen dan mendapatkan kesetianaan konsumen. Pengertian pelanggan disini berlaku juga terhadap layanan pada bagian lain di lingkungan internal perusahan/organisasi. (4) taat asas, Tidak saja harus memenuhi target, kualitas dan tepat waktu tapi juga harus dilakukan dengan cara yang benar.

Menurut Sutrisno (2009) ada enam indikator dari kinerja adalah sebagai berikut. (1) Hasil Kerja, meliputi tingkat kuantitas maupun kualitas yang telah dihasilkan oleh karyawanya dan sejauh mana pengawasan dilakukan oleh perusahaan. (2) Pengetahuan Pekerjaan, tingkat pengetahuan yang terkait dengan tugas pekerjaan yang akan berpengaruh langsung terhadap kuantitas dan kualitas dari karyawan yang berdampak pada hasil kerja. selain itu pengetahuan pekerjaan dapat mencerminkan sejauh mana karyawan dapat memahami produk atau jasa yang dimiliki perusahaan. (3) Inisiatif, tingkat inisiatif selama melaksanakan tugas pekerjaan khususnya dalam hal penanganan masalah-masalah yang timbul. Kemampuan mengenali masalah dan mengabil tindakan korektif, memeberikan saran-saran untuk peningkatan dan menerima tanggung jawab menyelesaikan. (4) Kecekatan Mental, Tingkat kemampuan dan kecepatan dalam menerima instruksi kerja dan menyesuaikan dengan cara kerja serta situasi kerja yang ada. (5) Sikap, perilaku karyawan tehadap perusahaan atau teman sekerja dan tingkat semangat kerja serta sikap positif dalam melaksanakan tugas pekerjaan. (6) Disipin Waktu dan Absensi, tingkat ketepatan waktu dan tingkat kehadiran karyawan ditempat kerja, untuk bekerja sesuai dengan waktu/jam kerja yang telah ditentukan perusahaan.

\section{Stres Kerja}

Menurut Garg (dalam Vijayan, 2017) stres kerja adalah hasil ketidakcocokan antara kemampuan individu dengan tuntutan organisasi atau target yang diberikan organisai. Menurut Rivai (2009: 108) stres kerja adalah kondisi ketegangan yang menciptakan adanya ketidak seimbangan fisik dan psikis, yang memengaruhi emosi, proses berpikir dan kondisi seseorang karyawan. Sedangkan menurut Mangkunegara (dalam Hanim, 2016) stres kerja adalah perasaan tertekan yang dialami karyawan dalam menghadapi pekerjaan yang diberikan perusahaan. Dari teori para ahli diatas dapat disimpulkan bahwa stres kerja adalah kodisi seseorang yang tertekan karena ketidakmampuan dalam menyelesaikan tugas yang diberikan oleh perusahaan.

Menurut Mangkunegara(2013: 108) stres kerja memiliki tiga dimensi sebagai berikut. (1) Beban kerja, adanya ketidaksesuaian antara peran yang diharapkan, jumlah waktu, dan sumber daya yang tersedia untuk memenuhi persyaratan tersebut. (2) Konflik peran, konflik peran merujuk pada perbedaan konsep antara karyawan yang bersangkutan dengan atasannya mengenai tugas-tugas yang perlu dilakukan. (3) Ambiguitas peran, ambiguitas peran berkaitan dengan ketidak jelasan tugas-tugas yang harus dilaksanakan seorang karyawan.

Menurut Hasibuan (2014) stres kerja memiliki lima indikator sebagai berikut. (1) Konflik, perbedaan pendapat antara dua atau lebih anggota organisasi atau kelompok. Diukur dari persepsi responden mengenai konflik antara karyawan dengan pemimpin. (2) Komunikasi, Proses pemindahan informasi dari seorang kepada orang lain dalam sebuah organisasi. komunikasi yang kurang baik antara karyawan dapat menyebabkan konflik. (3) Waktu Kerja, waktu untuk melakukan pekerjaan, diukur dari persepsi responden mengenai 
waktu kerja yang dirasakan berlebih. (4) Sikap Pimpinan, diukur dari persepsi responden mengenai sikap pemimpin yang kurang adil dalam memberikan tugas. (5) Beban Kerja, sesuatu yang dirasakan berada di luar kemampuan pekerja untuk melakukan pekerjaanya satunya dilihat dari target perusahaan.

\section{Kepuasan Kerja}

Wexley dan Yukl (2005) menyatakan bahwa kepuasan kerja merupakan cara seorang dalam merasakan dirinya atau pekerjaannya. Edison dkk (2017: 210) kepuasan kerja adalah seperangkat perasaan karyawan tentan hal-hal menyenangkan atau tidak terhadap suatu pekerjaan yang mereka hadapi. Menurut Robbins dan Coulter (2009) kepuasan kerja merupakan sikap umum seseorang terhadap pekerjaanya. Menurut Robbins (2006) kepuasan kerja adalah sikap umum terhadap pekerjaan seseorang yang menunjukan perbedaan antara jumlah penghargaan yang diterima pekerja dan jumlah yang mereka yakini seharusnya mereka terima. Dari pendapat para ahli diatas dapat disimpulkan kepuasan kerja adalah perasaan seseorang terhadap pekerjaan secara keseluruhan ataupun dari berbagai aspek pekerjaan.

Menurut Smith (dalam Munandar, 2004) menyatakan terdapat lima dimensi kepuasan kerja sebagai berikut. (1) Kepuasan terhadap pekerjaan itu sendiri, pekerjaan memberikan kesempatan karyawan belajar sesuai dengan minat serta kesempatan untuk bertanggungjawab yang dapat memberikan kepuasan sendiri dalam menjalani pekerjaanya. Dalam teori dua faktor diterangkan bahwa pekerjaan merupakan faktor yang akan menggerakkan tingkat motivasi kerja yang kuat sehingga dapat menghasilkan prestasi kerja yang baik. (2) Kesempatan terhadap gaji, kepuasan kerja karyawan akan terbentuk apabila besar uang yang diterima karyawan sesuai dengan beban kerja dan seimbang dengan karyawan lainnya. (3) Kesempatan promosi, promosi adalah bentuk penghargaan yang diterima karyawan dalam organisasi. Kepuasan kerja karyawan akan tinggi apabila karyawan dipromosikan atas dasar prestasi kerja yang dicapai karyawan tersebut. (4) Kepuasan terhadap supervise, hal ini ditunjukkan oleh atasan dalam bentuk memperhatikan seberapa baik pekerjaan yang dilakukan karyawan, menasehati dan membantu Karyawan serta komunikasi yang baik dalam pengawasan. Kepuasan kerja karyawan akan tinggi apabila pengawasan yang dilakukan supervisor bersifat memotivasi karyawan. (5) Kepuasan terhadap rekan sekerja, jika dalam organisasi terdapat hubungan antara karyawan yang harmonis, bersahabat, dan saling membantu akan menciptakan suasana kelompok kerja yang kondusif, sehingga akan menciptakan kepuasan karyawan dalam menjalani pekerjanya.

Menurut Luthans (2006: 115) terdapat lima indikator kepuasan kerja sebagai berikut. (1) Gaji, karyawan mendapatkan sistem gaji yang adil sesuai dengan pekerjaan yang dia kerjakan. (2) Pekerjaan itu sendiri, karyawan menyukai pekerjaan yang memberi kesempatan untuk menggunakan keterampilannya. (3) Rekan kerja, dalam peleksanaan kegiatan perusahaan rekan kerja harus dapat saling mendukung dalam lingkungan kerja. (4) Promosi, peluang karyawan dalam hal pengembangan karir di perusahaan agar karyawan termotivasi dalam bekerja. (5) Supervisi, kemampuan atasan memberikan pengaruh positif terhadap pekerjaan yang karyawan lakukan.

\section{Hubungan Stres Kerja Terhadap Kinerja Karyawan melalui Kepuasan Kerja}

Tinggi rendahnya kinerja karyawan dipengaruhi oleh stres kerja dan kepuasan kerja, stres kerja yang tinggi dan kepuasan kerja yang rendah menyebabkan kinerja karyawan kurang optimal. Hal ini sejalan dengan teori Handoko (2008) menyatakan bahwa stres kerja dan kepuasan kerja dapat memengaruhi kinerja karyawan itu sendiri. Teori tersebut sejalan dengan hasil penelitian oleh Dewi (2014) dan Wala (2017) bahwa stres kerja dan kepuasan kerja secara simultan berpengaruh signifikan terhadap kinerja karyawan. 
H1: Ada pengaruh secara signifikan stres kerja dan kepuasan kerja terhadap kinerja karyawan

\section{Hubungan Stres Kerja Terhadap Kepuasan Kerja}

Stres kerja dapat memengaruhi kepuasan dalam bekerja, dimana karyawan yang bekerja dalam tekanan akan merasakan ketidaknyamanan dalam mejalankan pekerjaan ini dapat memengaruhi tingkat kepuasan karyawan dalam bekerja, bebean kerja misalnya target yang terlalu besar. Menurut Hasibuan (2007: 204) stres karyawan timbul akibat kepuasan kerja tidak terwujud dari pekerjaanya. Hal ini sejalan dengan penelitian yang dilakukan oleh Amalia (2016) dan Dewi (2014) ada hubungan negatif dan signifikan stres kerja dengan kepuasan kerja. Berbeda dengan hasil penelitian Gofur (2018) stres kerja berpengaruh positif dan signifikan terhadap kepuasan kerja.

H2: Ada pengaruh secara signifikan stres kerja terhadap kepuasan kerja

\section{Hubungan Stres Kerja Terhadap Kinerja Karyawan}

Usaha untuk meningkatkan kinerja karyawan, diantaranya dengan memperhatikan tingkat stres kerja karyawan. Tingkat stres kerja yang tinggi maupun rendah jika berlangsung terus menerus dalam jangka waktu yang lama dapat menurunkan kinerja karyawan dikarenakan ada rasa tertekan dalam melaksanakan pekerjaan. Hal ini sejalan dengan teori Sasono (2004: 5) menyebutkan bahwa dampak negatif stres kerja dengan tingkat yang tinggi akan berdampak pada penurunan kinerja karyawan yang drastis. Hal ini sejalan dengan penelitian yang dilakukakan Amalia (2016) dan Wala (2017) stres kerja berpengaruh negatif terhadap kinerja karyawan. Berbeda dengan hasil penelitian Annisa (2017) stres kerja berpengaruh positif terhadap kinerja karyawan.

H3: $\quad$ Ada pengaruh secara signifikan stres kerja terhadap kinerja karyawan

\section{Hubungan Kepuasan Kerja Terhadap Kinerja Karyawan}

Perasaan puas dalam berkerja dapat meningkatkan kinerja karyawan, Jika karyawan menerima penghargaan yang mereka anggap pantas dan sepadan dengan pekerjaanya, karyawan akan menghasilkan kinerja yang lebih baik. Menurut Robbins (2006) dampak kepuasan kerja pada kinerja karyawan, karyawan yang merasa puas akan pekerjannya memiliki kemungkinan yang lebih besar membicarakan hal yang positif tentang organisasinya, membantu yang lain dan membuat kinerja pekerjaan mereka mencapai maksimal. Hal ini sejalan dengan penelitian yang dilakukan Fadhil (2018) dan Sari (2018) kepuasan kerja mempunyai hasil positif dan signifikan terhadap kinerja. Berbeda dengan hasil penelitian Kristine (2017) kepuasan kerja memiliki pengaruh negatif dan signifikan terhadap kinerja karyawan.

H4: Ada pengaruh secara signifikan kepuasan kerja terhadap kinerja karyawan

\section{METODE}

Penelitian ini dilakukan untuk mengetahui pengaruh stres kerja dan kepuasan kerja terhadap kinerja karyawan PT. BPR Sedana murni. Terdiri dari stres kerja $\left(\mathrm{X}_{1}\right)$, kepuasan kerja $\left(X_{2}\right)$ sebagai variabel bebas dan kinerja karyawan sebagai variabel terikat $(Y)$. Penelitian ini termasuk penelitian pendekatan kuantitatif kausal. Dari variabel tersebut ditentukan indikator, instrumen penelitian dan desain populasi yang digunakan. Selanjutnya mengumpulkan data dengan isntrumen penelitian berupa kuesioner. Lalu dilakukan uji reliabilitas, uji validitas data, uji hipotesis dan teknik analisis kuantitatif yang digunakan adalah analisis jalur. Hasil analisis data selanjutnya disajikan serta diinterpretasikan, langkah terakhir adalah teknik penarikan kesimpulan dan saran. Tahap dalam penelitian kuantitatif kasual terdiri dari rumusan masalah, mengkaji teori, merumuskan hipotesis, mengumpulkan data, mengolah data dan menarik kesimpulan. Dalam mencari pengaruh stres kerja $\left(\mathrm{X}_{1}\right)$ dan kepuasan kerja $\left(\mathrm{X}_{2}\right)$ terhadap kinerja karyawan $(\mathrm{Y})$ digunakan metode analisis jalur.

Subjek yang digunakan dalam penelitian ini adalah karyawan pada PT. BPR Sedana Murni. Objek penelitian ini adalah stres kerja $\left(X_{1}\right)$, kepuasan kerja $\left(X_{2}\right)$ sebagai variabel 
bebas dan kinerja karyawan $(Y)$ sebagai variabel terikat. Populasi dalam penelitian ini mengadopsi gagasan Sugiyono (2007) yakni keseluruhan seluruh karyawan PT. BPR Sedana Murni yang berjumlah 32 orang karyawan.

Pada penelitian ini, metode pengumpulan data yang digunakan yaitu pencatatan dokumen dan kuesioner. Pengumpulan data kuesioner dalam penelitian ini dilakukan dengan menyebar kuesioner dengan total 16 pernyataan kepada setiap karyawan PT BPR Sedana Murni. Pengumpulan data dengan pencatatan dokomen dalam penelitian ini didapatkan data pendapatan oprasional tahun 2019.

\section{HASIL DAN PEMBAHASAN}

Hasil berikut:

Hasil analisis jalur, maka diperoleh hasil penelitian seperti yang tampak pada Tabel 1

Tabel 1. Pengujian Hipotesisi

\begin{tabular}{c|c|c|c|c|l}
\hline Parameter & Koefisien & $p$-value & $A$ & Keputusan & \multicolumn{1}{|c}{ Simpulan } \\
\hline $\mathrm{R}^{2} \mathrm{yx}_{1} \mathrm{x}_{2}$ & 0,691 & 0,000 & 0,05 & $\begin{array}{c}\text { Menolak } \\
\text { Ho }\end{array}$ & $\begin{array}{l}\text { Ada hubungan } \mathrm{X}_{1} \text { dan } \mathrm{X}_{2} \\
\text { terhadap } \mathrm{Y}\end{array}$ \\
\hline $\mathrm{Pyx}_{1}$ & $-0,470$ & 0,002 & 0,05 & $\begin{array}{c}\text { Monak } \\
\text { Ho }\end{array}$ & $\begin{array}{l}\text { Ada hubungan pengaruh } \\
\text { negatif } \mathrm{X}_{1} \text { terhadap } \mathrm{Y}\end{array}$ \\
\hline $\mathrm{Pyx}_{2}$ & 0,438 & 0,004 & 0,05 & $\begin{array}{l}\text { Ada hubungan positif } \mathrm{X}_{2} \\
\text { terhadap } \mathrm{Y}\end{array}$ \\
\hline $\mathrm{Px}_{2} \mathrm{x}_{1}$ & $-0,678$ & 0,000 & 0,05 & $\begin{array}{c}\text { Menolak } \\
\text { Ho }\end{array}$ & $\begin{array}{l}\text { Ada hubungan negatif } \mathrm{X}_{1} \\
\text { terhadap } \mathrm{X}_{2}\end{array}$ \\
\hline$\varepsilon_{2}$ & 0,309 & - & - & - & $\begin{array}{l}\text { Hubungan pengaaruh } \\
\text { faktor lain terhadap }(\mathrm{Y})\end{array}$ \\
\hline$\varepsilon_{1}$ & 0,322 & - & - & - & $\begin{array}{l}\text { Hubungan pengaaruh } \\
\text { factor lain terhadap }\left(\mathrm{X}_{2}\right)\end{array}$ \\
\hline
\end{tabular}

Sumber: Pengolahan Data SPSS

Berdasarkan hasil perhitungan SPSS pada tabel 1 menunjukan bahwa stres kerja dan kepuasan kerja berpengaruh terhadap kinerja karyawan PT. BPR Sedana Murni. Pengaruh masing-masing variable dapat digambarkan pada Gambar 2 sebagai berikut.

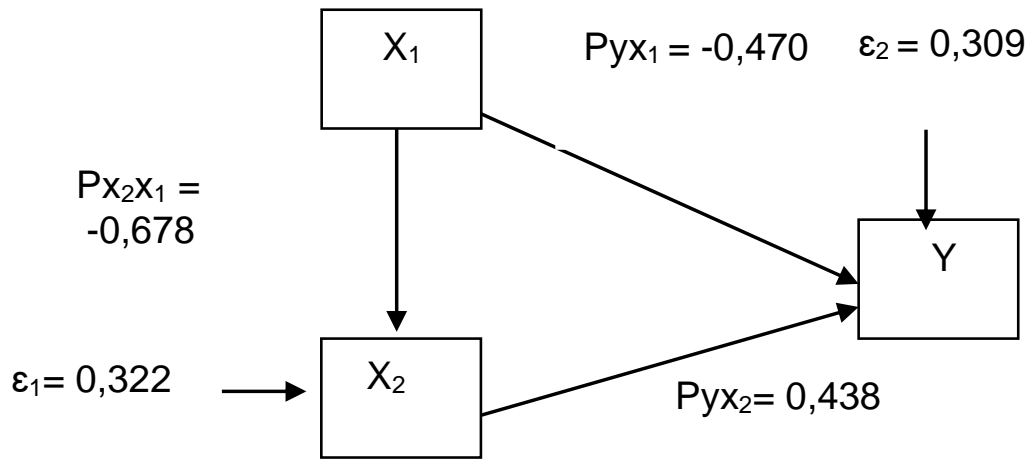

Gambar 4.1 Struktur Pengaruh Stres Kerja (X1) Terhadap Kinerja Karyawan (Y) Melalui Kepuasan Kerja (X2)

Besar sumbangan pengaruh langsung dan tidak langsung dari $\mathrm{X} 1$ tehadap $\mathrm{Y}$ Melalui X2 dalam penelitian ini dapat dilihat pada Tabel 2 . 


\begin{tabular}{l|c|c}
\hline \multicolumn{1}{c|}{ Keterangan } & Besar & Persentase \\
\hline Besar pengaruh langsung X1 terhadap Y & 0,470 & $47 \%$ \\
\hline $\begin{array}{l}\text { Besar pengaruh tidak langsung X1 } \\
\text { terhadap Y melalui X2 }\end{array}$ & 0,296 & $29,6 \%$ \\
\hline Besar pengaruh total X1 terhadap Y & 0,766 & $76,6 \%$ \\
\hline Besar pengaruh total X2 terhadap Y & 0,438 & $43,8 \%$ \\
\hline $\begin{array}{l}\text { Besar pengaruh total X1 dan X2 } \\
\text { terhadap Y }\end{array}$ & 0,691 & $69,1 \%$ \\
\hline Besar pengaruh lain terhadap Y & 0,309 & $30,9 \%$ \\
\hline
\end{tabular}

Sumber: Pengolahan Data SPSS

Berdasarkan hasil perhitungan uji statistic analisis jalur pada Tabel 2 menunjukan bahwa Stres kerja berpengaruh terhadap kinerja karyawan melalui kepuasan kerja pada PT. BPR Sedana Murni, hal tersebut ditunjukan dengan $p$-value Ryx1x2 =0,000< $\alpha=0,05$. Ada hubungan signifikan antara stres kerja terhadap kinerja karyawan melalui kepuasan kerja karyawan PT. BPR Sedana Murni sebesar 0,691 atau 69,1\% sedangkan besar pengaruh faktor lain terhadap kinerja karyawan yaitu sebesar 0,309 atau 30,9\%.

Stres kerja pengaruh negatif dan signifikan terhadap kepuasan kerja karyawan pada PT. BPR Sedana Murni. Hal tersebut sebesar 0,678 atau 67,8\% sedangkan besar pengaruh faktor lain terhadap kepuasan kerja yaitu sebesar 0,322 atau 32,2\%.

Ada hubungan pengaruh negatif dan signifikan antara stres kerja terhadap kinerja karyawan PT. BPR Sedana Murni. Besar sumbangan pengaruh stres kerja terhadap kinerja karyawan yaitu sebesar 0,470 atau $47 \%$.

Ada hubungan pengaruh positif dan signifikan antara kepuasan kerja terhadap kinerja karyawan PT. BPR Sedana Murni. Besar sumbangan pengaruh kepuasan kerja terhadap kinerja karyawan yaitu sebesar 0,438 atau $43,8 \%$.

\section{Pembahasan}

Berdasarkan penelitian yang telah dilakukan, maka diperoleh temuan bahwa variabel stres kerja memiliki pengaruh yang lebih dominan dalam memengaruhi kinerja karyawan melalui kepuasan kerja, hal tersebut dapat dilihat dari hasil pengaruh bersama-sama yang menyatakan stres kerja dan kepuasan kerja berpengaruh secara signifikan terhadap kinerja karyawan PT. BPR Sedana Murni. Hasil penelitian ini sejalan dengan teori yang disampaikan Handoko (2008) menyatakan bahwa stres kerja dan kepuasan kerja dapat memengaruhi kinerja karyawan itu sendiri. Didukung hasil penelitian Dewi (2014) dan Wala (2017) menunjukan stres kerja dan kepuasan kerja secara simultan berpengaruh signifikan terhadap kinerja karyawan.

Penelitian mengenai pengaruh variabel stres kerja terhadap kepuasan kerja, diperoleh hasil variabel stres kerja berpengaruh negatif dan signifikan terhadap kepuasan kerja karyawan PT. BPR Sedana Murni. Hal ini sejalan dengan teori yang disampaikan oleh Hasibuan (2007: 204) stres karyawan timbul akibat kepuasan kerja tidak terwujud dari pekerjaanya. Sejalan dengan hasil penelitian dari Amalia (2016) stres kerja memengaruhi kepuasan kerja pada PT. Bina Centra Swakarsa. Berbeda dengan hasil penelitian Gofur (2018) stres kerja berpengaruh positif dan signifikan terhadap kepuasan kerja. Pengaruh negatif dari stres kerja yang dialami karyawan dapat menurunkan tingkat kepuasan karyawan dalam menjalankan tugas yang diberikan oleh perusahaan, stres kerja perlu diperhatikan oleh pihak manajemen perusahaan untuk mengelola stres kerja dapat dilakukan pendekatan secara individu maupun bimbingan dari organisasi. 
Hasil penelitian selanjutnya mengenai pengaruh stres kerja terhadap kinerja karyawan PT. BPR Sedana Murni. Hal ini sejalan dengan teori yang disampaikan oleh Sasono (2004: 5) menyebutkan bahwa dampak negatif stres kerja dengan tingkat yang tinggi akan berdampak pada penurunan kinerja karyawan yang drastis. Sejalan dengan hasil penelitian Amalia (2016) dan Wala (2017) stres kerja berpengaruh negatif terhadap kinerja karyawan. Berbeda dengan hasil penelitian Annisa (2017) stres kerja berpengaruh positif terhadap kinerja karyawan. Jadi apabila perusahaan ingin meraih kinerja yang optimal di dalam pencapaian tujuan perusahaan, maka perusahaan haruslah memperhatikan tingkat stres kerja karyawannya, stres kerja karyawan yang rendah dapat memengaruhi kinerja karyawan dalam menyelesaikan tugas yang dibebankan perusahaan kepada karyawanya dan dapat meningkatkan hasil kerja individu dalam pencapaian kinerja.

Hasil penelitian selanjutnya yang diperoleh adalah variabel kepuasan kerja berpengaruh secara positif dan signifikan terhadap kinerja karyawan PT. BPR Sedana Murni. Hal ini sejalan dengan teori yang disampaikan oleh Robbins (2006) dampak kepuasan kerja pada kinerja karyawan, karyawan yang merasa puas akan pekerjannya memiliki kemungkinan yang lebih besar membicarakan hal yang positif tentang organisasinya, membantu yang lain dan membuat kinerja pekerjaan mereka mencapai maksimal. Didukung hasil penelitian Fadhil (2018) dan Sari (2018) kepuasan kerja mempunyai hasil positif dan signifikan terhadap kinerja. Berbeda dengan hasil penelitian Kristine (2017) kepuasan kerja memiliki pengaruh negatif dan signifikan terhadap kinerja karyawan. Hal ini menunjukan bahwa kepuasan kerja lebih berkaitan dengan peningkatan kinerja karyawan.

Keterbatasan dari penelitian ini yaitu pengamatan hanya dilakukan pada satu perusahaan saja, sehingga dari hasil penelitian ini belum bisa degeneralisasikan pada perusahaan lain. Di samping itu pula dari segi jumlah variabel yang digunakan cukup terbatas, diduga masih terdapat variabel lain yang memengaruhi kinerja karyawan. Dengan demikian diharapkan bagi peneliti lain untuk mengembangkan penelitian ini dengan mengkaji variabel yang digunakan untuk penelitian ini, serta subjek dan objek yang digunakan dapat lebih luas dalam penelitian.

\section{SIMPULAN DAN SARAN Simpulan}

Berdasarkan hasil penelitian dan pembahasan yang telah dijelaskan, maka dapat disimpulkan hal sebagai berikut.

(1) Stres kerja dan kepuasan kerja berpengaruh terhadap kinerja karyawan pada PT. BPR Sedana Murni. Hal ini stres kerja memiliki pengaruh yang lebih besar dalam meningkatkan kinerja karyawan dan kepuasan kerja juga memiliki peran yang dalam upaya peningkatan kinerja karyawan. (2) Stres kerja berpengaruh negatif dan signifikan terhadap kepuasan kerja pada PT. BPR Sedana Murni. Semakin tinggi stres kerja yang dialami karyawan maka akan berdampak pada menurunnya tingkat kepuasan kerja karyawan. (3) Stres kerja berpengaruh negatif dan signifikan terhadap kinerja karyawan pada PT. BPR Sedana Murni. hal ini menunjukan bawah stres kerja mampu memengaruhi kinerja karyawan, jika stres kerja yang dialami karyawan tinggi maka semakin rendah kinerja yang dihasilkan karyawan. (4) Kepuasan kerja berpengaruh positif dan signifikan terhadap kinerja karyawan pada PT. BPR Sedana Murni hal ini menunjukan jika karyawan merasa puas dalam menjalani pekerjaanya dapat meningkatkan kinerja karyawan.

\section{Saran}

Berdasarkan simpulan yang telah dikemukakan, makan dapat diajukan beberapa saran yaitu sebagai berikut. (1) Bagi pihak manajemen PT. BPR Sedana Murni, agar lebih memperhatikan stres kerja dan kepuasan kerja agar dapat meningkatkan kinerja karyawanya, hasil penelitian ini menunjukan bahwa stres kerja dan kepuasan kerja dapat memengaruhi kinerja karyawan. Dengan memperhatikan stres kerja karyawan dapat 
meningkatkan kepuasan kerja karyawan. (2) Bagi peneliti selanjutnya yang tertarik untuk mengkaji aspek yang sama yaitu tentang stres kerja dan kepuasan kerja serta kinerja karyawan, diharapkan dapat mengembangkan penelitian ini dengan menguji variabel lain yang diduga kuat memengaruhi kinerja karyawan seperti motivasi kerja, pengalaman kerja, dan lingkungan kerja.

\section{DAFTAR PUSTAKA}

Amalia, Uzzah Roni. 2016. "Pengarus Stres Kerja dan Kepuasan Kerja Terhadap Kinerja Karyawan". e-Jurnal Bisma Universitas Pendidikan Ganesha, Volume 4.

Annisa, Nenden Nur. 2017. "Pengaruh Stres Kerja Terhadap Kinerja Karyawan Dengan Kepuasan Kerja Sebagai Variabel Intervening". Jurnal Eprints, Volume 4.

Arda, Mutia. 2017. "Pengaruh Kepuasan Kerja dan Disiplin Kerja Terhadap Kinerja Karyawan Pada Bank Rakyat Indonesia Cabang Putri Hijau Medan". JIMB, Volume 18.

Arfani, Rizal. 2018. "Pengaruh Stres Kerja Dan Beban Kerja Terhadap Kinerja Karyawan Di PT. Sucofido Cabang Bandung". e-Proceeding of Management, Volume 5, Nomor 2.

Dewi, Novi Charisma.2014. "Pengaruh Stres Kerja Dan Kepuasan Kerja Terhadap Kinerja Karyawan Pada Bagian Tenaga Penjualan UD SURYA RADITYA NEGARA". $e-$ Jurnal Bisma Universitas Pendidikan Ganesha Jurusan Manajemen, Volume 2.

Edison, Emron, dkk. 2017. Manajemen Sumber Daya Manusia. Edisi kedua. Bandung: ALFABETA cV.

Fadhil, Achmad. 2018. "Pengaruh Motivasi Kerja dan Kepuasan Kerja Terhadap Kinerja Karyawan AJB Bumiputra". Jurnal Administrasi Bisnis, Volume 54, Nomer 1.

Gofur, Abdul. 2018. "Pengaruh Stres Kerja Terhadap Kepuasan Kerja Karyawan". Jurnal Riset Manajemen dan Bisnis, Volume 3.

Hakam, Malik. 2015. "Analisis Jalur Terhadap Faktor-Faktor Yang Memengaruhi Indeks Prestasi Kumulatif (IPK) Mahasiswa Statistik UNDIP”. Jurnal Gaussian, Volume 4, Nomer 1.

Handoko, T. Hani. 2008. Manajemen Personalia dan Sumber Daya Manusia. Edisi 2. Yogyakarta: BPFE.

Hanim, Maslatifa. 2016. "Pengaruh Stres Kerja Terhadap Kepuasan Kerja Serta Dampak Pada Kinerja Karyawan Hull Construction di PT DOK dan Perkapalan Surabaya". Jurnal IImu Manajemen, Volume 4, Nomer 3.

Hasibuan, Malayu S. P. 2007. Manajemen Dasar, Pengertian, dan Masalah. Jakarta : Penerbit Bumi Aksara.

Hasibuan, Malayu S. P. 2014. Manajemen Suber Daya Manusia. Edisi Revisi. Jakarta : Bumi Aksara.

Kristine, Erline. 2017. "Pengaruh Kepuasan Kerja Dan Komitmen Organisasi Terhadap Kinerja Melalui Motivasi Kerja Pegawai Alih Daya (Outsourcing) Di PT. Mitra Karya Jaya Sentosa". Jurnal EKSEKUTIF, Volume 14, Nomor 2.

Luthans, Fred. 2006. Perilaku Organisasi. Edisi Ke-10. Yogyakarta: Andi.

Mangkunegara, A. A. Anwar Prabu. 2013. Manajemen Sumber Daya Manusia Perusahaan. Bandung: Remaja Rosdakarya.

Massie, Rachel Natalya. 2018. "Pengaruh Stres Kerja Terhadap Kinerja Karyawan Pada Kantor Pengelola It Center Manado". Jurnal Administrasi Bisnis. Voleme 6, Nomer 2.

Munandar, AS. 2004. Peran Budaya Organisasi dalam Peningkatan Untuk Kerja Perusahaan. Jakarta : Fakultas Psikologi Universitas Indonesia.

Ni'mah, Ulin. 2017. " Pengaruh Motivasi, Kepuasan kerja dan Disiplin kerja Terhadap Kinerja Karyawan (Studi Pada Karyawan Loenpia Mbak Lime)". Jurnal Unpad, Volume 3, Nomor 3. 
Rivai, Veithzal, dkk. 2009, Kepemimpinan dan Perilaku Organisasi, Jakarta : PT Rajagrafindo Prasada.

Robbins, Stephen P. 2006. Perilaku Organisasi. Edisi Ke-10. Penerbit PT.Indeks, Kelompok Gramedia. Jakarta.

Robbins, Stephen P dan Mary Coulter. 2009. Management. Edisi Ke-10. New Jersey : Pearson.

Sari, Rindiantika. 2018. "Pengaruh Kepuasan Kerja Terhadap Kinerja Karyawan Dengan Organizational Citizenship Behavior Sebagai Variabel Intervening (studi pada karyawan PTPN X - Unit usaha pabrik gula Modjopangoong)". Jurnal Administrasi Bisnis, Volume 64, Nomor 1.

Sasono, Eko. 2004. "Mengelola Stres Kerja". Jurnal Fokus Ekonomi, Volume 3, Nomor 2.

Setyawibowo, Wahyu. "Pengaruh Kepuasan Kerja Terhadap Kinerja Karyawan PD BPR BANK Daerah Gunungkidul". e-Proceeding of Management, Volume 4, Nomor 1.

Sugiyono. 2007. Metode Penelitian Bisnis. Bandung: CV. Alfabeta.

Sutrisno, Edy. 2009. Manajemen Perilaku Organisasi. Jakarta : Kencana.

Uno, Hamzah B dan Nina Lamatenggo. 2012. Teori Kinerja dan Pengukurannya. Jakarta : Bumi Aksara.

Vijayan, Mathangi. 2017. "Impact Of Job Stress On Employees' Job Performance In Aavin, Coimbatore". Jurnal of Organisation \& Human Behaviour, Volume 6.

Wala, Framelita Mariana. 2017. "Pengaruh Stres Kerja dan Kepuasan Kerja Terhadap Kinerja Karyawan Pada Kantor Pelayanan Kekayaan Negara dan Lelang Manado". Jurnal EMBA. Volume 5, Nomer 2.

Wexley KN dan Yukl GA. 2005. Perilaku organisasi dan psikologi personalia, Jakarta: Bina Aksara.

Widiarian, Neddiar. 2017. "Pengaruh Stres Kerja dan Lingkungan Kerja Terhadap Kinerja Karyawan KPPN Merauke". Jurnal IImu Manajemen, Volume 3, Nomer 3.

Wirawan. 2009. Evaluasi Kinerja Sumber Daya Manusia Teori Aplikasi dan Penelitian. Jakarta. Penerbit: Salemba Empat. 